\title{
A REVIEW OF THE EPIDEMIC OF INFLUENZA AT THE BASE HOSPITAL, CAMP BEAUREGARD, IA., WITH SPECIAL REFERENCE TO SYMPTOMS AND SEQUELE.
}

\author{
By Donald J. Frick, M.D., Majon, M.C., U.S.A., \\ LOS ARGgLEs, CahronNia.
}

Tue epidemic began September 21. Cases began to be sent in to the hospital on September 24.

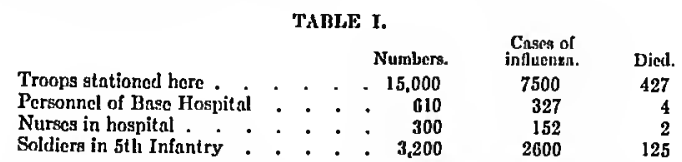

This table gives some idea of the way the Camp, as a whole, and different organizations were affected. The Fifth Infautry was more severely attaeked as the epidemic first appeared there, and the disease was most virulent in the beginning. Of the eommand approximately 50 per eent. had the discase. Of the 7500 eases of inthenza, 1474 developed pneumonia, or 19.6 per eent. Of these 1474 eases of pneumonia, 427 died, a mortality of 29 per cent.

We have placed the period of the epidemic from September 24 to Oetober 18, 1918, as sinee the latter date admissions have been normal. A good many of the complientions and sequele here reeited have stretehed over a longer period.

Charts I and II give salient features of the epidemic. Chart I shows the patients in hospital day by day and Chart II the daily admissions, ineluding pnenmonias in hospital as reported (not as they appeared) and deaths day by day.

The Disease. A special report is made in the paper by Capt. MeClelland on the bacteriology of the cases of influenza and the pneumonia enses following the influevza. On the day that the first case appeared in the hospital we realized the enormous amount of work that would be thrown on the laboratory staff by such an epidemic, so the commanding officer asked the laboratory men of the different organizations mobilizing here to come into the inboratory and immedintely take up the task with Capt. Henderson, of working out the etiologieal faetor of the epidemic. Their work has been of wonderful value and satisfaction to us all.

As is shown in their report tlie ctiological factor was the influenza bacillus and the disease a true influenza.

The symptoms were of exeecling variety as to severity and kind. Most of the eases had severe backache, lieadache, a racking cough, flushed face, injeeted eyes, and, as a rule, a pulse between 80 and 100 , with a temperature from $101^{\circ}$ to $104^{\circ}$. Most all of them were dull and apathetie, went to sleep in the ambulanee, shept on the litter while they were being enrried into the hospital and harl to be 
aroused to answer questions. They only roused up to eougl, take medieine or nourishment. They all looked prostrated and siek. All slept twelve hours, some sisteen to twenty-four hours. The fever and prostration in the mild cases lasted forty-eight hours, the

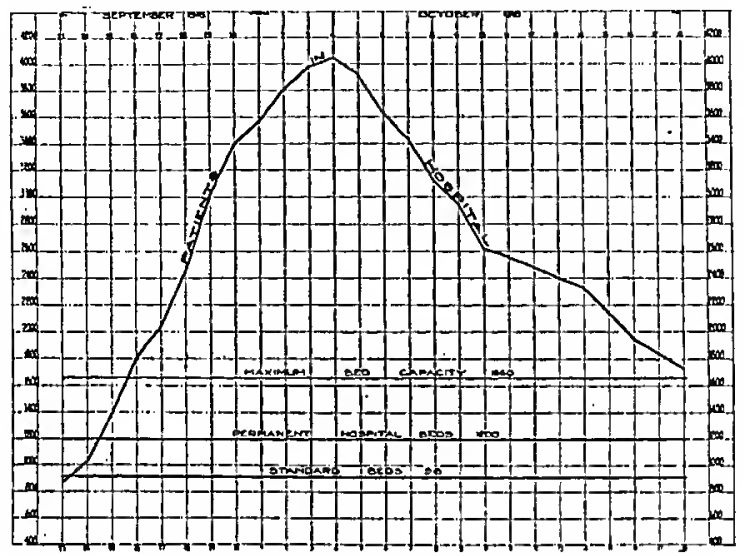

Crcant 1.-Patients in hospital day by day.

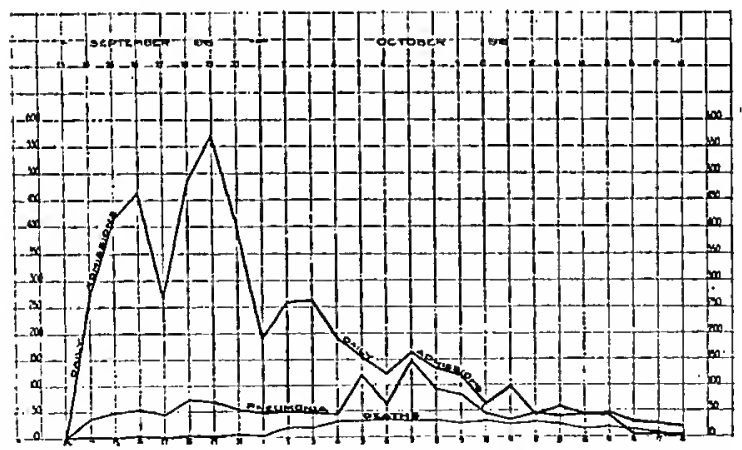

Chant II.-Daily admission, slowing pneunonias in hospital n.s reported and denths day by dny.

patients then began to get up and sit on the edge of the beds. They were all weak and some fainted in trying to get out of bed. The more severe eases had fever for three or four days. Praetically all eases that had fever longer than this proved to have bronehopneumonia. Many had vomiting; some became tender over the 
abdomen, imitating an intra-abdominal eondition. (See Appendix I for a typical case, Chart 3.)

There was a leukopenia in practically all enses and no rise of leukocytes with the advent of pneumonia.

Besides the ordinary symptoms, a striking feature in the early stages of thesc cases was the bleeding from some portion of the body: Our statisties show that 15 per cent. suffered from epistaxis. Everywhere one went he saw mon with bleeding or packed noses. Fifty eases of subeonjunctival hemorrlage werc counted. 'Twelve had a true hemoptysis, bright red blood with 110 admixtıre of ınucus. Six cases vomited blood. One ease died from loss of blood from this causc. Among the nurses, menstruation began in about 80 per cent. two or three days after going to bed. Threc cases hal intestinal hemorrhage. Most of the blecding eaine early, witl the exeeption of three eases of hemoptysis, which came after broncloplicimonin had begun.

Twelve to fifteen per cent. of all cases had herpes eitlier of the lips, tongue, nose or mouth, the eruption bcing excedingly extchsive in some eases.

Pneumonia developed secondarily to the influenza in 1342 enses, and the eomplieations given below must be regarded as complieations of this disease, in most eases, rather than influenza.

Jaundice of a mild or severe degree developed in 112 cases of bronchopneumonia. In those recovering the jaundiee disappcared very rapidly, in some enses clearing up entirely in seven or eight days. The liver in all eases seen was enlarged, so we believe it was a truc elolangitis.

Otitis media las been reported in 41 eases. l'ortunately the otologists were on duty day and night and did immediate paraeentesis on all bulging drums. No mastoid operations so far lave been necessary.

Infectious psychoses were seen in 18 cases, the patients cxhibiting all grades of aberration from simple transient hallucinations to maniaeal frenzy whieh necded mechanical restraint for twelve to twenty-four hours. Two of these cases have not clcared up at this date, one being free of all other signs and symptoms for four clays; the other still having signs of his bronchopneumonia.

Two cases developed an hysterieal aphonia (which elcared up in three and eight days respeetively).

Five cascs of pneumococcus meningitis were diagnosed clinically and proved positive by lumbar puncture; 6 to 8 cases were punctured that had some signs of meningitis; these all showed a clear fluid under pressurc, no increase in cells and no bacteria.

Eleven cases of epidemic cerebrospinal meningitis werc diagnosed and isolated during the epidemie; 3 cases developed after the patients were convalescing from pneumonia and had been in the hospital from three to four weeks. Report of this will be made later.

Cases with a frietion rub were of such common occurrence that 
we lave not been able to give any reliable statisties as to numbers on them.

Empyema eases lave appeared at the end of the epidennic. 'Twenty-nine have been reported so far, 3 eases showed liemolytic streptoeoceus, 20 cases pneumococci, 7 cases no organism found.

The most interesting complieation on aecount of its usual rarity has beell interstitial emphysema, of which we have had 10 eases. Hlistories of the first ease, with pieture by Capt. A. L. Levin, and one of the two eases that have lived are liereby appended. (See Appendix I.) Also an autopsy report by Capt. Sehultz on one of the cases. (See Appendix II.) The only reason that ean be given for the great number of these cases is the violenee of the eough and the degenerative changes brought about in the disease. All of these eases had influenza, followed by bronehopneumonia, the subeutaneous emphysema eoming from six to ten days after the beginning of the disease. The air was first felt in all eases in a eollar about the neek and then gradually spread over the back, cliest and arms to the hands as far as the knuckles and down the thighs to the middlle. A rupture of the bronchus at the root of the lung seeins to 1 s the only explanation.

Two cases after violent coughing developed a pneumothorax, the heart being pushed to the right as far as the midline on that side. (For autopsy on one case see Appendix II.) Onc case has proved to be a pyopneumothorax.

Capt. Levin presents a brief history and autopsy findings in one of the most remarkable cases of the epidemie, gangrene of the eolon with rupture. (Appendix I.)

Briefly, in this paper, we have given the unusual complieations in this epidemic. Unfortunately, we did not have the time or the facilities for doing some of the work that should have been done.

Wc ean give no reason for the frequeney of hemorrhages, but eanuot help feeling that there must have been some definite elange in the eonstituents of the blood, although we made no estimation of the eoagulation and bleeding time nor eounted platelets.

The effeet of the influenza baeillus must be to prepare a fertile field for the pneumoeoecus, as we have never seen sueh virulent pneumonias either primary or secondary to measles. Death came rapidly and eould be prognosticated praetieally from the moment the man entered the hospital. The objeet of this paper and appendiees is to put on reeord for further use the disease as we have seen it. This should be worth while.

\section{APPENDIX 1 .}

Case I.-Case of influenza; no complications.

Reg. No. 23,718. M. J., Pvt., Co. C, Dev. Bn. Admitted Oetober 23, 1918. Family II istory and past history not important. Present Illness. Onset sudden, with aching over the whole body and pains in the head and eough. 
Examination. Signs of a bronchitis. Sputum shows Bacillus influenza and Type IV pucumococcus.

Blood Connt. Whites, 5000; polymorphonuclears, 48 per cent.

Urine. Negative. (Chart III.)

CASE II.-Case of interstitial emphysema bilateral (died).

Reg. No. 19343. C. J. R., white, aged twenty-three years. Native of Louisiana, carpenter, robust physique. Four months in service. Onsct of influenza September 23, 1918. Admitted September 24, 1918. Symptoms of influenza. Diagnosed: Bronchopneumonis at base of right lung on September 30, 1918. Coughed

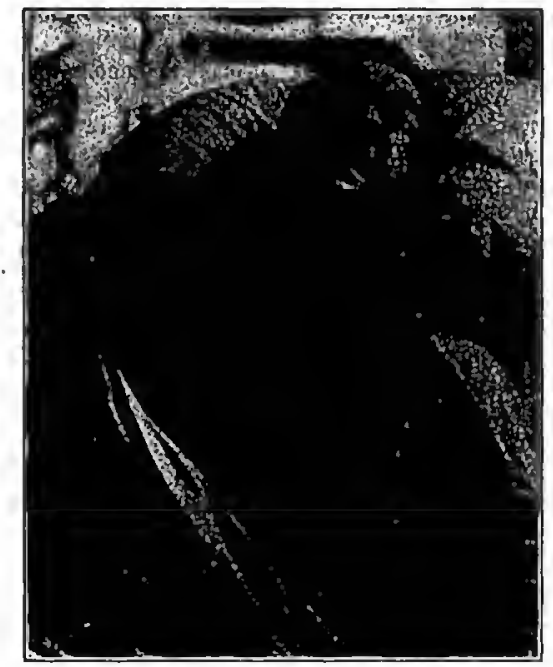

Fia. I (Case 11).-Showing bilaternl interstitial cmpyemas.

violently when temperature lowered; cautioned about it. Began to improve when subeutancous emphysema developed at 3 r.M. on October 6, 1918. Died at 10 A.Mr., Oetober 8, 191 S.

Past Ilistory. Malaria, treated at Base Hospital.

Diagnosis. Interstitial emphysema bilnteral.

Result. Death. (Fig. 1, Cliart IV.)

Case III.-Case of interstitial emphysems (with recovery).

leg. No. 22920. II. N., Pvt., Co. K, 5t] Infantry. Admitted to hospital October 5, 1918. Diagnosed: Brouchopncumonia October 8, 1918.

October 12. Became delirious nnd unmanngeable.

October 13. Subentancous emphysemn developerl orer the'left 


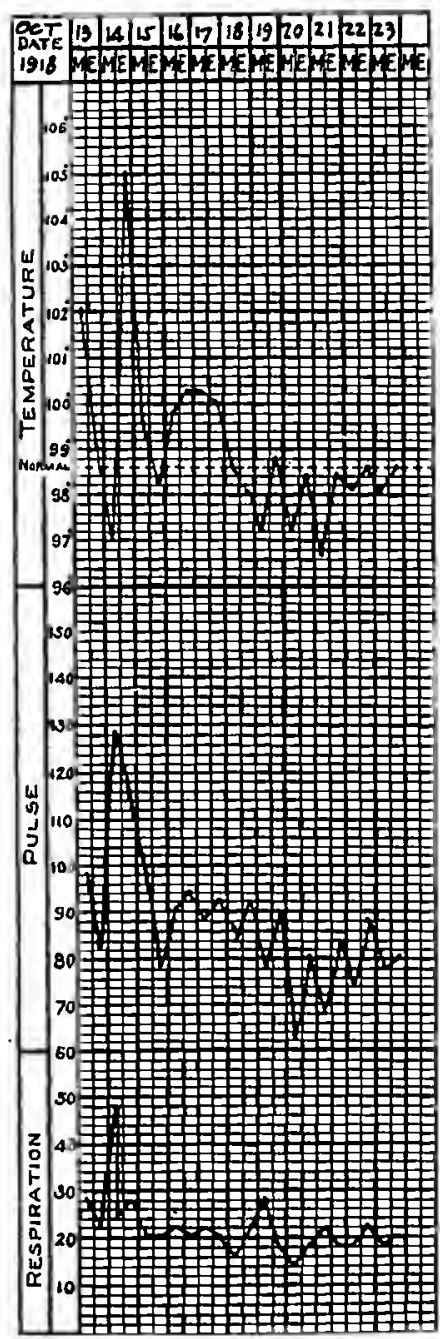

Chart III.-Clinical chart of Caso I, uncomplicated caso of influenza. 


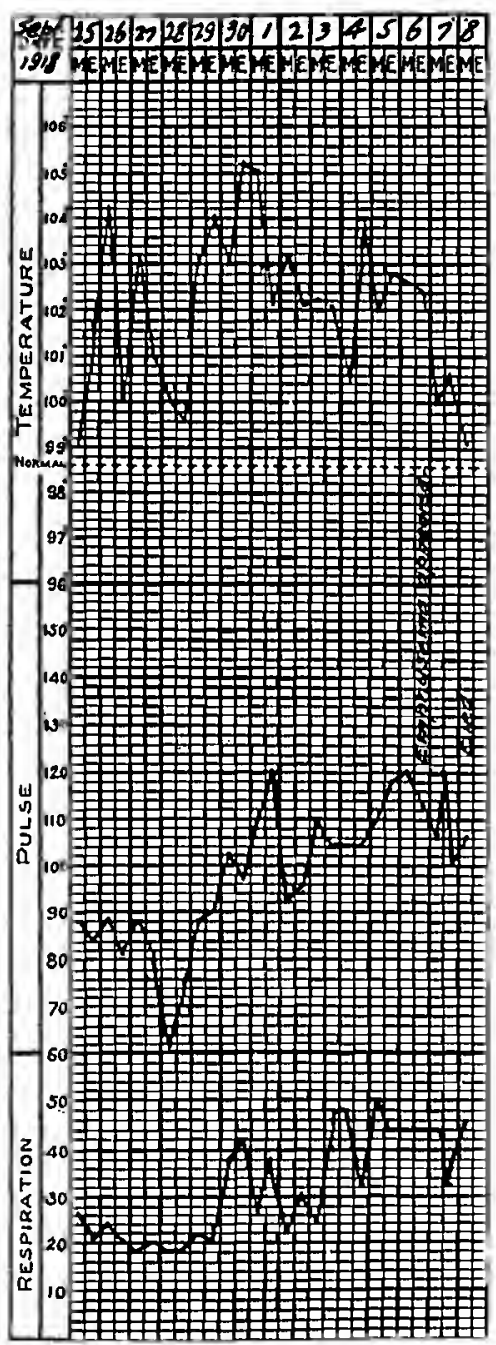

Cusur IV.-Clinieal chart of Cass H. Fatal biluteral interstitinl emphysepa. 
eliest, left arm and hand. Same day developed a tremor over the whole body; eyes wild and staring; talks incessantly.

Oetober 16. Patient wants food; lungs better.

Oetober 20. Emphysema practieally disappeared exeept under left claviele.

Oetober 28. Practieally well; chest clear; emplysema gone. (Chart V.)

Case IV.-An unusual complication of bronchopnenmonia, 'lype III.

Reg. No. 23476. C. C., Pvt., Co. (i, 29th Infantry. Miner by occupation. Three and a lialf years in servicc. Admitted Oetober 9,1918 , with influcnza. Bronchopnenmonin detected on October 11, 1918, left lung, 'Type IlI sputum and blood eulture.

Oetober 18. Marked abdominal distention notieed (upper ahdomen).

October 10. Purulent pleural fluid obtained; culture: pncmmoeoecus, 'lypc 11I. I'lastic pneumococcus peritonitis suspeeted on Oetober 20.

Oetober 23. 1)istention relieverl.

October 25. I'us obtained from left chest. Operated on the sume evening, 9.30 P...r. Dyspnea, eyanosis, collnpse. Died 11.50 P....

Oetoler 26. Autopsy: Plastic pneumocoecus peritonitis, rupture of transverse colon the entire length; gangrenous, fecul matter frecly in poeket. 'Transverse colon cight inches in diameter; small and large intestines agghtinated.

APPEND]X 11.

Autopsy Protocol, No. 1.

Name: E. V.

lank: Sergeant, Co. E, 5th Infantry.

Alitopssy No. 6.

T'ime of death: 2 x...s., Septcmber 2S, 1918.

'Time of autopsy: 9 А...., September $28,1918$.

Admitted: September 20, 1918.

Clinical Diagnosis. Lobar pneumonit, right lower.

Anatomical Diagnosis. (1) Aeute entarrhal bronchitis;

diffuse bronchopneumonia of both lower lobes; (3) aeute liemorrhagic plcuritis of right lung; (4) aeute splenic tumor; (5) eloudy swelling of liver, kidneys and myocardium.

Fxtemal Examination. The body is that of a well-developed, white male, about seventy-one inches long, weighing about 185 pounds. Strong rigor is present, and there is marked lividity of the posterior surface of the body and of the left side of the face. 'There are no external marks of injury or of identification.

Internal Exomination. A thin layer of subcutaneous fat is present. The peritoneal eavity is free of adhesions and of fluid. The pericardial eavity contains a shight excess of fluid which is partly elotter. The left pleural eavity is normal. The right contains a slight excess of fluid, which is faintly clouded and slightly blood-tinged. 


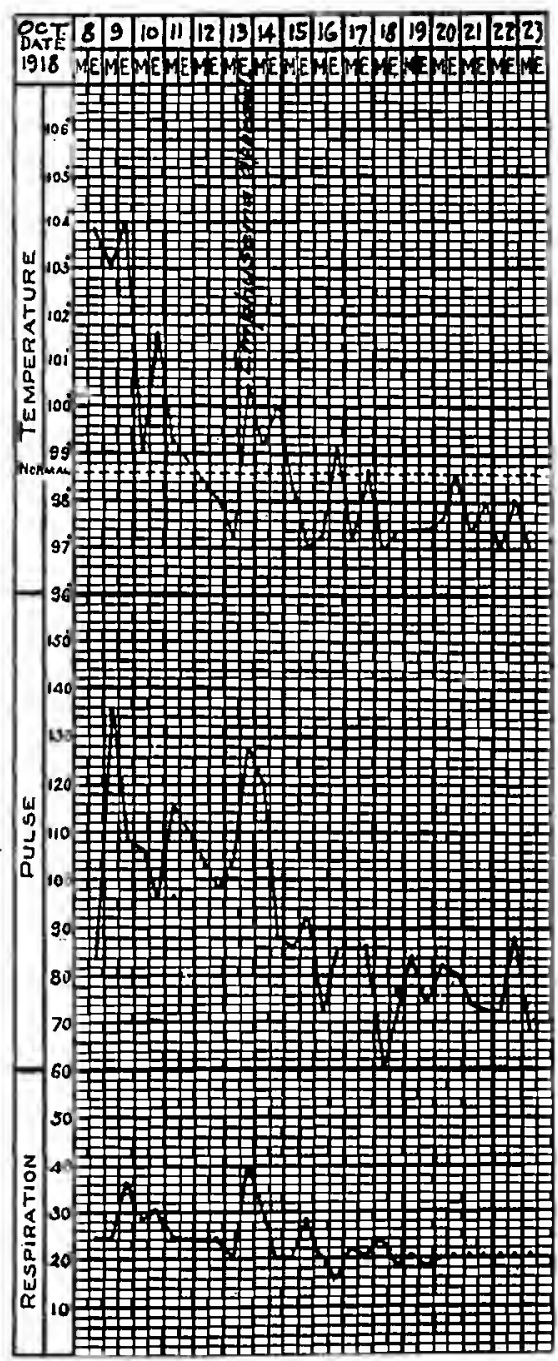

Cun vt V.-Clinical chart of Case HI. Interstitial emphysema, with recovery. 
Langs. The pleural surfaee of the left is smooth and glistening. 'The lower lobc, although it eontains air, feels heavier and less crepitant than normal. On seetion the lower lobc is eongested, and the ent surfaee, from which frothy fluid eseapes, is very finely granular, the appcarance suggesting the consolidation of inmumerable groups of small numbers of alveoli, these being separated by small groups of air-containing alveoli. The upper left lobe is erepitant and pale pink in eolor. The pleura of the lateral surfaee of the right lung is finely graular and henorragie, but its surfaee eontains the fibrin. The lower lobe is engested, and like the lower left lobe is heavier and less erepitant than normal. On seetion it is somewhat more decply congested than the lower left lobe, but lins the same very finely granular appearanee. The upper and middle left lohes appear normal. The broneli of both limgs are decply eongested, but eontain no exudate.

Ileart. The right side is distended with blood. All the valves and the root of the aorta are normal. The heart inusele is pale and eloudy.

Splecn. The splecn is cnlarged to about three times the normal and fecls rather soft. The outer surface is sniooth and is dark bluish red in color. On scetion the tissuc is dark red and muel blood escapes from the surface.

Liver. Normal externally. On section the tissue is clondy. Gall-. bladder and duets are normal.

Kidneys. Each is slightly inereased in size. On seetion the cortex is swollen and cloudy and the glomeruli stand ont as minute, slightly congested points.

Idrcnals, pancreas, gastro-intestinal tract, bladdor and prostato. Negative.

Bacteriology. Cultures from the heart's blool and from the fluid of the right pleura show no growth. Smcars from the lower lobes of the lumgss show Gram-negative small bacilli and Gram-positive diploeoeei. Cultures from the lung yickd B. inllucurat and a Grampositive, bile insoluble, non-licmolytie streptoeoeens.

$$
\text { Autopsy Prolocol, No. } 2 .
$$

Name: F. W.'T.

Rank: Pvt., Co. E, Dev. Bn.

Admitted: September 29, 1918.

Died: 9 A.M., October 4, 1918.

Autopsy: 10 A.M., Oetober 4, 1918.

Clinical Diagnosis. Lobar pneumonia.

Anatomical Diagnosis. (1) Lobar pneunonin of the right lower lobe (red hepatization); (2) pseudolobar pncumonia of the left lower lobe; (3) bronehopneumonia of both upper lobes and of the right middle lobe; (4) aeute catarrhal bronelitis of hoth limgs; (5) aeute fibriopurulent pleuritis of right lung; (6) acute splcnic tumor; (7) eloudy.swelling of liver, myoeardium and kidneys.

External Examination. The body is that of a slenderly built 
white male, about seventy inches tall, weighing about 146 pounds. The body is still warm and rigor is absent. The neck and face are cyanotic. On the inner surface of the left knee is a large old scar of a burn.

Internal Examination. Peritoneal, pcricardial and left pleural cavity are normal. A thin layer of yellow exudate is present over the lower outer half of the right upper lobe and between the lobes.

Lungs. The lower lobe of the left lung is occupied by irregularly shaped confluent patches of dark red, airless tissue, which is congested and granular on section. A smaller wedge-shaped area is present at the lower border of the right upper lobe. The right lower lobe is completely consolidated and on section the tissue is dark red and granular and contains mucl blood. A few small patches of consolidation are present in the right upper and middle lobes. The bronchi of both lungs are congested and contain no exudatc.

Heart. Negative except for eloudy swelling of the muscles.

Splecn. 'The spleen is increased to twice the normal sizc. On section the tissuc is dark red and soft.

- Liver. Cloudy.

Kidneys. The cortex is swollen and cloudy.

Adrenals, pancreas, gastro-intestinal tract, bladder and prostate. Negative.

Bacteriology. Smears from the right upper and lower lobes and from the pleural exudate contain many Gram-positive diplococci. Cultures from these situations contain pneumococci. Culture from the spleen is negative. The heart's blood culture is contaminated by a large Gram-negative bacillus, but contains Gram-positive diplococci, which prove to be Type IV pneumococci in the peritoneal cxudate of a mousc injected with the culture.

Name: R. F.

$$
\text { Autopsy Protocol, No.s. }
$$

Rank: Pvt., Co. H., 5th Infantry.

Admitted: September 26, 1918.

Died: 12.50 P.M., October 10, 1918.

Autopsy: 3.30 P.M., October 10, 1918 .

Clinical Diagnosis. Influenza. Bronchopneumonia of the left lower lobe. Interstitial emphysema bilateral.

Anatomical Diagnosis. Interstitial emphysema bilateral. Pseudolobar pneumonia of both lower lobes; (2) bronchopneumonia of both upper lobes and of the right middle lobe; (3) interstitial empbysema of the mediastinum and of the subcutaneous tissne of the face, neck, thorax and arms.

External Examination. The body is that of a sparely built white male about sixty-six incbes tall, weighing about 130 pounds. Rigor and lividity are not present. The skin of the right side of the face and of the entire neck appears swollen, and on pressure it has a crepitant crackling feel. The same crepitant sensation is elicited upon pres- 
sure of the skin of the chest anteriorly as far down as the nipple linc, laterally on both sides of the chest to a slightly lower level and about half-way down on both arms. The skin of the crepitant regious is not discolored.

-Internol Examinotion. The peritoneal cavity is normal. When the sternum is removed the tissues of the mediastinum are found filled with air, which occurs in the form of bubbles of varying sizc held in the loose tissues. The loose tissues of the root of the neck show a similar condition. The pericardial cavity is normal. Both pleural cavities arc free of fluid and of adhesions. The lungs are not collapsed and no air is present in the pleural cavities.

Lungs. The two lungs are removed in toto, together with the trachea. Bubbles of air are present beneatli the pleura of the left lung; these bubbles follow the lines of the interlobular septa. The pleura of each lower lobe posteriorly and laterally is granular and cloudy, but no macroscopic fibrin is present. All the loose tissue about the roots of the lungs contain bubbles of air. The lungs feel heavy, the lower lobes being enlarged and dark red in color. Areas of consolidation are present in both upper lobes, and about half of the right middle lobe is solid. Although the lower lobes arc almost completely consoliclated, small areas of rir-containing tissucs are present at the margins and in several places beneath the plcura. When the lungs are immersed in water and inflated by a tube placed in the trachica a steady stream of air bubbles escapc from the tissue at the bifurcation of the trachea, the air apparently coming from the left bronchus anteriorly at the level of the bifurcation. On openiug the trachen a small tear is found in the mucosa of the anterior wall of the left bronchus in the region from which the air was seen to escape. On section of the lungs both lower lobes are dark red and granular. Scattered about in the dark red tissue are numerous more opaque gray areas two or three lobules in sizc; these arcas appear to have a peribronchial distribution. The right middle and both upper lobes contain areas of consolidation, of varying size, which are grayish red in color and rather soft and friable. The bronchi contain no exudate and their mucosa is not reddened.

Spleen. The spleen is moderately enlarged, firm and dark red. The remaining organs were not examined further.

Bacteriology. Smears and cultures from the right lower love show nothing. Cultures from the spleen and heart's blood remain stcrile. Smears from the left lower lobe show a few Gram-positive diplococci; the cultures show numerous Gram-negative small bacilli and Gram-positive cosci in pairs and chains. The latter type are Type III pneumococcus.

Name: W. McC.

Autopsy Protocol No. 4 .

Rank: Pvt., Co. A, M. P.

Died: 5.15 A.M., October 20, 1918. 
Autopsy. 11.00 A.M., Oetober 20, 1918.

Clinical Diagnosis. Pneumothorax.

Anatomical Diagnosis. Pneumothorax (left); suppurative pneumonia of the left lung; bronchopneumonia in the right.

Histological seetion of the tissue of the right lung, left lung and spleen.

External Examination. The body is that of a well-developed male, weight about 165 pounds, six feet in height. Rigor mortis is present. The skin is clear and there are no deformities or marks; the appearance of his face indicates some emaciation.

Internal Examination. An incision is made from the suprasternal notch to the pubes. The subcutaneous tissue is in good shape.

Langs. The left lung has completely eollapsed. It is nodular, grayish in eolor which is due to a fibrinous exudate, but there are no adhesions and a little fluid containing pus in the pleural envity. On seetion pus flows freely from every nodule. The lung is full of abscesses ranging from the size of a hen's egg to minute abseesscs. The bronchi are filled with pus. The right lung has a consolidation in the lower posterior portion of the upper lobe involving the upper posterior third of the lower lobe. The rest of the lung feels as though it is in fairly good shape with plenty of air in it. On section there is pus in the consolidated portions and also, some little pus in the bronchi. The air cells in the scemingly good portions of the lung contain in various areas a little frothy fluid but there are no evidences of inflammation. There are no adhesions cxcept the adjacent consolidated portion. There is little fluid in the right pleural cavity.

Jleart. The heart is negative.

The liver, pancreas, intestines and pcritoneum are all negative.

Splcen. The spleen has an infarct about the size of a fifty-cent piece on the upper anterior third. On section it seems inflamed and is somewhat enlarged.

Kidney. The right kidney is large, red and seems swollen, and the capsule peels off easily, but on seetion it is negative. The left kidney seems identical with the right. The appendix is negative.

\title{
BACTERIOLOGICAL OBSERVATIONS ON THE EPIEMIC OF INFLUENZA AT CAMP BEAUREGARD, LA.
}

\author{
By J. I. McClelland, M.D., Captain, M.C., U.S.A., \\ CLEVEtAND, OBTO.
}

Tusre has been so much discussion and uneertainty, so mueh euriosity and inquiry regarding the etiological factors in the prevailing epidemie of so-called Spanish influenza, that it is deemed appropriate to report the results of our work at this Base Hospital. 